\title{
Across establishments, within firms: worker's mobility, knowledge transfer and survival
}

\author{
Marisa Fernanda Figueiredo Tavares ${ }^{*}$ (i)
}

\begin{abstract}
We analyze the recruitment strategies and the survival of newly created establishments that are affiliated with preestablished_rms. For the new establishments, the existence of ports of entry as well as the importance of internal and external recruitment is assessed. Being affiliated with a pre-established firm may be a source of competitive advantage and improve the new plant's chances of survival as the parent firm may supply the newly created unit with expertise and firm-specific knowledge. In this research we suggest a channel for knowledge transfer that has been little addressed in previous literature: within firm and across establishments mobility of workers. As firm-specific knowledge is mainly embodied and non-tradable, we suggest that it can be successfully transferred to the new unit embodied in the workers that are internally recruited. We find that internally transferred workers, particularly skilled workers hired at high-rank jobs play an important role in improving the survival of new establishments.
\end{abstract}

Keywords: Worker's mobility, Knowledge transfer, New establishment's survival

JEL Codes: J61, J62, L25

\section{Introduction}

The determinants of new plants survival has been the subject of extensive previous research. The present work builds upon an important piece of this literature that examines the survival and hazard rates of new plants that are affiliated with pre-established firms. While some previous research takes for granted that the affiliation to an existing firm brings increased and easier access to knowledge, in this paper we extend the study of the channels by which the parent firm (or other units in the same group) can transfer knowledge to the newly opened branch. Our research contributes to the literature by focusing on a specific mechanism of within-firm transfer of knowledge that has been relatively neglected so far-the transfer of workers from pre-existing to newly-created establishments of the same firm. The novelty in our work lies in the use of a large matched employer-employee data set to focus on the role that intra-firm mobility plays as a

\footnotetext{
*Correspondence: mtavares@porto.ucp.pt

Universidade Católica Portuguesa, Católica Porto Business School, Rua de Diogo Botelho, 1327, 4169-005 Porto, Portugal
}

channel for transferring knowledge and expertise to the new unit and to analyze the impact of this internal recruitment strategy in the new unit's survival. These internal movements not only strengthen personal ties between different plants but they are also a direct channel for knowledge transfer that has been scarcely addressed in previous literature.

The objectives of this paper are twofold. Our first objective is to characterize the recruitment policy of new establishments affiliated with multi-establishment firms, analyzing the importance of internal and external hires at different hierarchical levels. Our hypothesis is that, in the new unit, internal transfers will increase for higher hierarchical levels (Doeringer and Piore 1971; Lazear and Oyer 2004). The second objective of this paper is to asses if internal hires, specially at higher hierarchical levels, affect the survival of new establishments. This is an indirect way to test if intra-firm mobility is motivated by the need to transfer firm-specific knowledge to the new unit. Our main hypothesis is that the share of internal hires positively affects survival because it works as a channel for knowledge transfer. We believe this channel 
can work in two ways: first, a higher proportion of internally hired employees can increase personal contacts and acquaintances between the new plant and the other units of the group improving and smoothing communication. Second, a higher proportion of internal hiring will be particularly important in top-level jobs, where strategic decision-making occurs. As firm-specific human capital is embodied in the workers, it may be supplied to the new unit by internally transferring workers. Implementing other effective strategies to transfer knowledge to the new unit may be particularly challenging for tacit knowledge that is hard to codify.

Our findings show that external hires seem to prevail for occupations that are closer to the bottom of the hierarchy, which sustains the existence of ports of entry, while internal hires prevail at the top. We also conclude that the share of internal hires, particularly for higher-rank jobs, has a positive impact on survival and that internal transfers are likely to be one important channel to transfer firm-specific knowledge to new establishments.

The rest of the paper is organized as follows: in Sect. 2 we present relevant previous research; in Sect. 3 we detail our sample design and characterize the data; Sect. 4 discusses the empirical strategy and presents the main results and Sect. 5 concludes.

\section{Previous research}

It has been found that the factors affecting the survival of new entrants are different depending on wether the entry is attempted by a new or by an already established firm (Dunne et al. 1988, 1989; Audretsch and Mahmood 1994; Mata et al. 1995; Mitchell 1994). Being owned by a pre-established firm may provide the new plant several types of advantages. These entrants may have better access to resources and financial markets, since they are affiliated with a pre-existing firm that has built a reputation (Brito and Mello 1995), and being affiliated to a group can also be an important source of economies of scale (Ingram 1996). The parent firm may also supply expertise in management and operational knowledge which can help the new plant in the development of a successful entry strategy that will positively affect the new unit's survival. As successful firms are those that develop firm-specific assets that cannot be imitated by competitors, this puts the ultimate source of competitive advantage of a firm in its workers (Darr et al. 1995; Youndt et al. 1996; Wernerfelt 1984; Barney 1991; Teece 1998). Analyzing the importance of knowledge transfer, Ingram and Baum (1997) evaluated the importance of chain affiliation in the Manhattan hotel industry, while Darr et al. (1995) studied organizational learning and the transfer of knowledge among pizza stores, and Greve (1996) examined radio broadcasters which shared a common corporate owner. These studies emphasize the importance of knowledge transfer within organizations and conclude that being part of a chain of firms may improve the chances of survival of individual businesses.

Identifying the channels by which the transfer of knowledge occurs is also a central issue and different channels have been proposed in the literature. Some argue that this transfer results from regular communication that can facilitate the diffusion of innovation and the transfer of technology (Tushman 1977; Ghoshal and Bartlett 1988; Rothwell 1978), while others emphasize the importance of personal acquaintances and personal ties in the transfer of learning (Huberman 1983; Martilla 1971; Liebenz 1982; Tushman 1977). Dutton and Starbuck (1978) discuss the importance of regular meetings as a channel to transfer learning since more opportunities for communication and competence sharing among corporate units would result in self-imitation within the corporation (Greve 1996) and learning would occur in the form of intraorganizational mirroring behavior (Ingram and Baum 1997).

We build upon this literature by focusing on a specific mechanism of within-firm transfer of knowledge that has been scarcely addressed in previous literature-the transfer of workers from pre-existing to newly-created establishments of the same firm. As tacit knowledge and firm-specific human capital is mainly embodied in the workers and incorporated in the organization's routines and processes (Nelson and Winter 1982; Coff 1997; Teece 1998), analyzing intra-firm transfers is one way to asses the importance of knowledge transfer to the new unit's survival.

Intra-firm mobility is also an essential question in personnel economics. When a pre-established firm considers the decision to open a new establishment, it has to make choices on how to fill the vacancies created in the new plant. The firm has two options: hire in the external labor market or fill the vacancy through internal reallocation, transferring an employee from another unit within the same organization. Internal hires are a central channel to transfer and retain firm-specific human capital in internal labor markets (ILM) (Doeringer and Piore 1971). In essence, the decision on how to fill the vacancies in the newly created establishment is akin to the internal transfers decision which is central to the ILM literature. Although ILM literature typically focuses on singleestablishment firms (Baker et al. 1994a, b), in multi-plant firms, the existence of an internal labor market will not be restricted to one particular establishment but will comprise the whole firm, necessarily including all the units affiliated with the same parent firm. The hypothesis that, in multi-establishment firms, internal labor markets 
comprise the firm as a whole, including all its units, is discussed in Tavares et al. (2018)

As mentioned previously, intra-firm mobility is a natural response to the existence of specific human capital (Becker 1962). ${ }^{1}$ A well known paper from Gibbons and Waldman (1999) develops on the role of learning and human capital acquisition as possible explanations for the observed career paths inside the organization. Once a worker acquires firm-specific human capital, his value inside the firm deviates from that at other firms. The longer the worker's tenure, the more specific human capital is accumulated and the more costly it would be for the firm to find an external candidate that outperforms internal workers. For newly created establishments this argument is particularly relevant as the internally transferred employees may be responsible for expertise transfer that can be crucial to the new unit's survival.

Considering the extension of the internal labor markets' theory to a multi-plant framework (Tavares et al. 2018) we will be interested in analyzing the existence of ports of entry. In the newly created establishment some jobs will be filled with workers working in other units of the same firm, whereas other jobs will be filled with individuals hired outside the firm. The latter are, in the ILM terminology, the ports of entry to the establishment, and again, according to the ILM literature, are those jobs within the establishment that require less firm-specific human capital. These are, presumably, lower-rank jobs. Higher-rank jobs, on the contrary, require more firm-specific human capital which can only be acquired by working in the firm. Hence, these jobs will be filled from within, i.e., through internal transfers of workers from pre-existing establishments to the new one. The strategic decisions that affect the new plants survival are more likely to be defined at higher hierarchical levels. On this premise, Lima and Martins (2006) assess the impact of external recruitment of top managers on firm performance and several studies on managerial succession address the impact of internal versus external hiring of CEO (Lauterbach et al. 1999; Furtado and Karan 1994) and of CEO turnover (Murphy 1999; Huson et al. 2004) on the firm's performance. Chan (1996) argues that internal employees hired to high positions are more likely to have been hired on the basis of their ability providing another argument why internal hiring at top levels is particularly relevant.

\footnotetext{
${ }^{1}$ Several factors may explain the creation of internal labor markets. ILM may be a response to imperfect information about the optimal job assignment for each worker (Jovanovic 1979) or may result from the firm's incentives structure (Lazear 1979). Moreover, risk-averse employers may prefer to hire from within, as internal employees' ability can be observed with less noise (Greenwald 1979).
}

\section{The data}

The data set in this study was constructed using Quadros de Pessoal (QP; Personnel Records), a rich matched employer-employee data set. QP is an annual mandatory employment survey collected by the Portuguese Ministry of Labor, Solidarity, and Social Security that all firms with wage earners are legally obliged to fill in. The coverage and reliability of the data set is one of its advantages. The data include establishment-specific details (employment, location, industry), information on the firm with which the establishment is affiliated (location, industry, number of establishments, employment, sales, ownership, legal framework), and workforce characteristics (gender, age, education, occupation, tenure, earnings, hours of work). The data set has a longitudinal dimension. Firms, establishments and workers entering the database are assigned a unique identifying number which allows to track them over time and to match workers with their firms and establishments.

We use the 2003 to 2008 waves of QP. The data corresponding to years 2003 to 2005 are used to identify the creation of new establishments. ${ }^{2}$ We want to analyze short-term survival so, each new establishment is followed for 3 years after its creation: units created in 2003 are followed until 2006, the ones created in 2004 are tracked until 2007 and new establishments in 2005 are followed until 2008. We identify an establishment entry whenever information for that establishment is reported to QP for the first time in the corresponding spell, i.e., if the establishment is not present in any of the preceding waves of the data. ${ }^{3}$ Similarly, we will identify an establishment exit in one year whenever information for the establishment is absent for that year and for all subsequent years, i.e., if the establishment is not present in any of the subsequent waves of the data. We do not make use of the waves of data available since 2008 as we don't wish to contaminate the analysis with the effects of the severe crisis that hit the Portuguese economy following the international recession.

In the data set, an establishment is defined as a single business location of a firm, new establishments being assigned different identification numbers. Given this definition, we will observe an opening if the firm creates a new establishment but also if an existing establishment is relocated or if a new plant is created after the merger and/or closure of previously existing units of the firm. As shown in Table 1, 1,57,953 new establishments were

\footnotetext{
${ }^{2}$ We didn't want to analyze a period of strong economic expansion or recession so 2003 to 2005 was selected because the Portuguese output gap was relatively low.

${ }^{3}$ For each year, we use all previous spells of the data (since 1985) to identify an entry.
} 
Table 1 Characterizing new establishments, 2003-2005

\begin{tabular}{lllll}
\hline & $\mathbf{2 0 0 3}$ & $\mathbf{2 0 0 4}$ & $\mathbf{2 0 0 5}$ & $\mathbf{2 0 0 3 - 2 0 0 5}$ \\
\hline $\begin{array}{l}\text { Number of new establish- } \\
\text { ments }\end{array}$ & 50942 & 46805 & 60206 & 157953 \\
$\begin{array}{l}\text { Number of workers } \\
\begin{array}{l}\text { Estab. average number of } \\
\text { workers }\end{array}\end{array}$ & 235343 & 203918 & 255731 & 694992 \\
\hline
\end{tabular}

Table 2 Characterizing firms, 2003-2005

\begin{tabular}{llll}
\hline & $\mathbf{2 0 0 3}$ & $\mathbf{2 0 0 4}$ & $\mathbf{2 0 0 5}$ \\
\hline Number of firms: & 45,335 & 41,789 & 53,989 \\
Single-establishment & 39,627 & 36,395 & 48,370 \\
Multi-establishment & 5708 & 5394 & 5619 \\
Firm average number of estab. & 1.6 & 1.6 & 1.6 \\
Firm average number of workers & 13.6 & 13.2 & 12.1 \\
Firm average age (in years) & 4.9 & 5.0 & 6.9
\end{tabular}

created in the 3 years period between 2003 and 2005 . These new establishments employ almost 700 thousand workers. In Table 2 we observe that newborn units are affiliated with firms that have, on average, 1.6 establishments and 13 workers. We also observe that more than three fourths of the entries are affiliated with singleestablishment firms, that are predominant in the data.

For the purpose of this paper, we are interested in newly created establishments for which the corresponding parent firm has the option to transfer workers from another establishments within the organization. For this possibility to be real, the new units in our sample have to be affiliated to a firm that pre-existed before the opening. Our sample is further restricted to newly created establishments that belong to firms that remain or become multi-establishment after the opening. Therefore, we keep new establishments that are affiliated with firms that are multi-establishment in both periods, before the opening and in the year of the opening, but also firms that grow from single to multi-establishment firm. The cases of single-single or multi-single were excluded as these are either firms that closed down an establishment and opened a replacement establishment (possibly due to relocation of the existing plant) or firms that closed all its pre-existing establishments merging them into a newly created unit. In both cases, the "new" establishments are likely to be transformations of pre-existing establishments rather than truly new units. Under these circumstances, internally transferred workers will necessarily come from establishments that were closed and these transfers are expected to be driven by different factors than those that we seek to investigate in this study.
Table 3 Sample characterization-new establishments, 2003-2005

\begin{tabular}{lllll}
\hline & $\mathbf{2 0 0 3}$ & $\mathbf{2 0 0 4}$ & $\mathbf{2 0 0 5}$ & $\mathbf{2 0 0 3 - 2 0 0 5}$ \\
\hline Number of new establishments & 8481 & 7749 & 7933 & 24,163 \\
Number of workers & 67,191 & 61,981 & 69,574 & $1,98,746$ \\
$\begin{array}{c}\text { Estab. average number of work- } \\
\text { ers }\end{array}$ & 8.3 & 8.4 & 8.7 & 8.5 \\
\hline
\end{tabular}

Table 4 Sample characterization-firms, 2003-2005

\begin{tabular}{llll}
\hline & $\mathbf{2 0 0 3}$ & $\mathbf{2 0 0 4}$ & $\mathbf{2 0 0 5}$ \\
\hline Number of firms & 4523 & 4310 & 4339 \\
Firm average number of estab. & 6.5 & 6.6 & 7.0 \\
Firm average number of workers & 93.0 & 91.4 & 103.9 \\
Firm average age (in years) & 15.2 & 15.2 & 15.0 \\
\hline
\end{tabular}

Moreover, we don't include in the sample establishments created by firms that close during the follow-up period as, in this case, the closure of the establishment is a consequence of the closure of the entire firm and the workers will necessarily lose their jobs not having the possibility of being transferred to another establishment of the same firm (the occurrence of establishment closures driven by entire firm exits was less than $1 \%$ of our sample).

Our final sample contains 24,163 newly created establishments that are affiliated to a pre-established parent firm that is multi-establishment after opening the new branch and that remains open during the follow-up period. ${ }^{4}$ Our sample of new establishments represents $15 \%$ of total openings in the period 2003-2005 and is responsible for $29 \%$ of the employment created by all new establishments. When compared to the total group of entrants, the new establishments in our sample have twice as many workers, even though, most of them, are still small, with $55 \%$ employing 3 workers or less.

Looking at the characteristics of the parent firms in our sample, as we restricted to multi-establishment firms after the opening, it is not surprising that the parent firms in our final sample are considerably larger having, on average, 7 establishments and almost 100 workers. On the other hand, as we kept only firms that pre-existed, the fact that the firms in our sample are older is also expected. Tables 3 and 4 characterize our final sample and Fig. 1 characterizes the firms in the sample according to the number of establishments owned. We observe that

\footnotetext{
${ }^{4}$ We observed that 32,803 are affiliated with firms that existed in the previous period but, out of these, 8411establishments were linked to firms that were single-establishment after the opening and were dropped from the sample.
} 


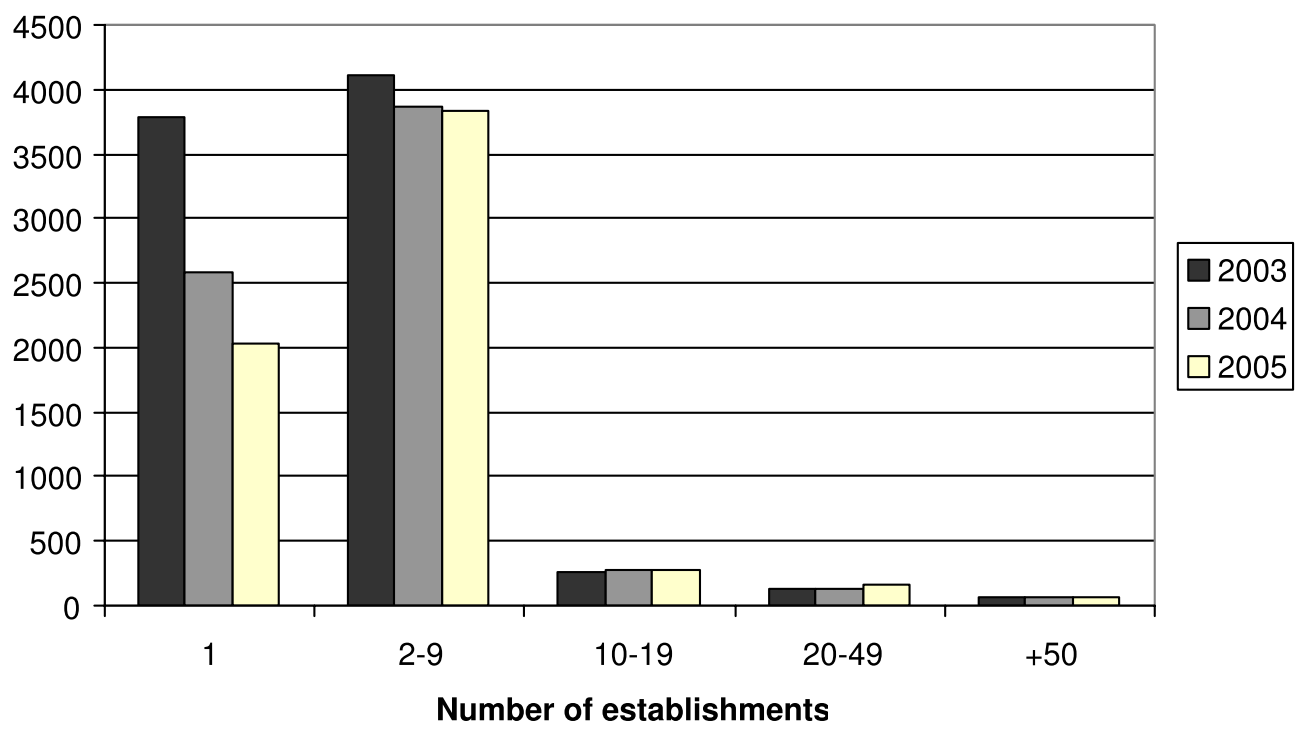

Fig. 1 Sample characterization: firms by number of establishments, 2003-2005

a large majority of multi-establishment firms have less than 10 establishments.

\subsection{Identifying internal hires}

Matching information on workers, establishments and their firms we are able to classify workers according to their origin. Internal hires in period $t$, worked for the same employer but in another establishment of the firm in the year $t-1$. For these workers, we observe a change in the establishment's identification number but the firm's identification number remains unchanged., 6 Workers that meet this criterion may be in two different situations:

1. The worker is transferred from an establishment that remains active (henceforth, Type I transfers);

2. The worker is transferred from an establishment that ceased its operations (henceforth, Type II transfers).

This distinction is important because the decision to transfer workers from establishments that close (Type II transfers) is driven by different factors than those

\footnotetext{
${ }^{5}$ We also included in this category workers that, in the previous year, don't appear in the dataset but show a tenure higher than 12 months. This indicates that they already worked for that same firm in the previous year but, for some reason, were not reported.

6 This classification is straightforward if the individual works only for one employer. When the individual, in year $\mathrm{t}-1$, worked for more than one firm we classify him as an internal hire provided that the individual worked for the firm that is opening the new establishment even if he also worked for other firms.
}

determining Type I transfers, as they are an alternative to a dismissal rather than a transfer driven move.

Most remaining hiring situations are classified as external hirings. External hires include workers that, in the previous wave of the data, were:

1. Employed with a different firm (henceforth, External: Other firm);

2. Not present in the data set in the previous year, meaning that they were either out of the labor force (new labor market entrants or re-entrants), unemployed, self-employed or employed as a civil servant (henceforth, External: Outside QP).

We found, however, one last case of hirings that we cannot classify into any of the above types of hiring, internal or external. This is a category of workers that are employed at time $t$ in a newly created establishment and undergo a change in the identification number of the firm they are working for but their reported tenure is longer than 12 months. This situation may be due either to workers hired externally that were able to secure whatever tenure they accumulated in their previous job (which may be important for certain types of employer-provided benefits), or to workers that are hired from other firms belonging to the same "economic group" as the destination firm. In the former case, but not in the latter these are, indeed, external hires. As we cannot separate one situation from the other, we classify these situations into a separate group (henceforth referred to as uncertain origin hires). The incidence of these cases although small is 


\section{Internal Labour Market External Labour Market}

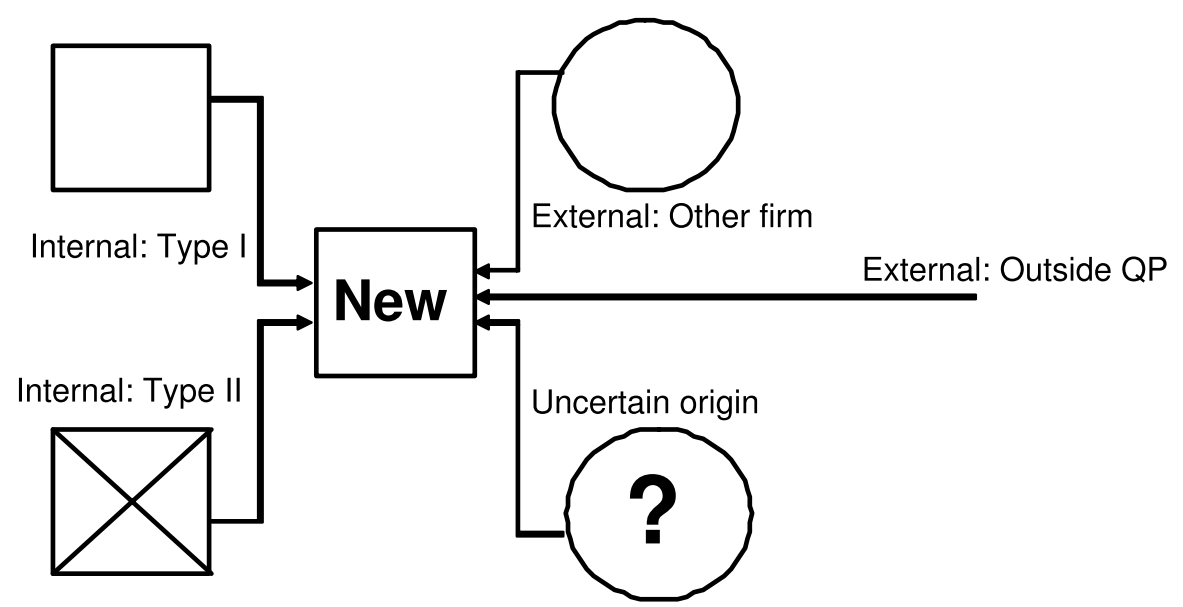

Fig. 2 Types of recruitment

not trivial. ${ }^{7}$ In Fig. 2 we summarize the five origins that we consider in the empirical work.

\subsection{Characterizing the data}

In this section we further characterize the newly created establishments in our final sample as well as their personnel. Looking at the establishments' distribution by economic activity and considering the Portuguese Classification of Economic Activity (cae), ${ }^{8}$ in our sample, cae $\mathrm{G}$, wholesale and retail trade, stands out, accounting for $40 \%$ of the new plants. Financial activities, real estate, renting and business activities (cae J and cae $\mathrm{K}$ ) rank second accounting for more than $20 \%$ of the new units in our sample. Regarding the geographical distribution, we observe some regional concentration with $31 \%$ of the establishments located in the Lisbon area.

Table 5 characterizes the new plant's personnel in terms of its origin in the internal or external labor markets. In our sample and for the all period 2003-2005, we observe that, on average, around $40 \%$ of the workers are hired in the external labor market: $15 \%$ of which are hired from another firm, while $25 \%$ are not present in the data set in the year before the opening. We also observe $8 \%$ of uncertain origin hires.

Therefore, we find that more than half of the workforce in the new establishment is recruited inside the parent firm. This proportion may seem surprisingly high but is

\footnotetext{
${ }^{7}$ In Table 5 we observe that uncertain origin transfers represent $8 \%$ of total hires.

8 Equivalent to the Standard Industrial Classification (SIC) codes (see Appendix B).
}

Table 5 Type of hiring per yea, 2003-2005

\begin{tabular}{|c|c|c|c|c|}
\hline Type of hiring & $2003(\%)$ & $2004(\%)$ & $2005(\%)$ & $2003 / 2005(\%)$ \\
\hline Internal (total) & 54.0 & 55.3 & 46.1 & 51.8 \\
\hline Internal: Type | & 28.8 & 33.1 & 25.7 & 29.2 \\
\hline Internal:Type II & 25.2 & 22.2 & 20.4 & 22.6 \\
\hline External: outside QP & 22.8 & 24.7 & 28.7 & 25.3 \\
\hline External: other firm & 13.0 & 15.2 & 16.3 & 14.8 \\
\hline Uncertain origin & 10.2 & 4.8 & 8.9 & 8.1 \\
\hline
\end{tabular}

better understood if we look at the proportion of internal transfers from establishments that remain open (Internal: Type I). For Type I internal transfers, the proportion drops to $29 \%$, leading us to conclude that several openings may be linked to a closure or a relocation of one (or more) previously existing units. Nevertheless, depending on the year, we observe that between one fourth and one third of the workforce is internally hired from existing establishments that remain open, confirming the importance of intra-firm hires in opening events.

The proportion of internal and external hires varies depending on the hierarchical level and occupation. In Table 6 we analyze the type of hiring by hierarchical level. ${ }^{9}$ We find that internal hiring is more important for top and intermediary executives as well as for supervisors while external hiring is predominant for lower skilled professionals. Our data also includes information about the workers' occupation, distinguishing between nine major occupational categories according to the National

\footnotetext{
${ }^{9}$ We distinguish eight hierarchical levels defined by law: Decreto-Lei no. 121/78, 2 Junho (see Appendix A).
} 
Table 6 Type of hiring by hierarchical level: 2003-2005

\begin{tabular}{lllllllll}
\hline Type of hiring & Level 1 & Level 2 & Level 3 & Level 4 & Level 5 & Level 6 & Level 7 & Level 8 \\
\hline Internal (total) (\%) & 74.2 & 61.1 & 71.3 & 59.2 & 53.1 & 50.3 & 48.1 & 31.9 \\
Internal: Type I (\%) & 41.8 & 34.5 & 37.2 & 33.9 & 27.9 & 27.6 & 24.2 & 16.6 \\
Internal: Type II (\%) & 32.4 & 26.6 & 34.1 & 25.3 & 25.2 & 22.7 & 23.9 & 15.3 \\
External: outside QP (\%) & 9.1 & 7.1 & 10.0 & 10.1 & 21.3 & 28.8 & 29.5 & 46.8 \\
External: other firm (\%) & 9.4 & 9.2 & 11.5 & 8.7 & 14.6 & 16.0 & 15.2 & 17.2 \\
Uncertain origin (\%) & 7.3 & 22.6 & 7.2 & 22.0 & 11.0 & 4.9 & 7.2 & 4.1 \\
Number of estab. (\%) & 4238 & 4292 & 4467 & 4975 & 15519 & 6170 & 4710 & 3641 \\
\hline
\end{tabular}

Classification of Occupations (NCO). ${ }^{10}$ Overall, external labor market hires seem to prevail for occupations that require less skills and that are closer to the bottom of the hierarchy. ${ }^{11}$ We observe that internal hiring becomes more important as we move up the job ladder. The lower levels, in the typical establishment, are much more likely to be hired from the outside while the upper levels are much more likely to be hired from within. This is consistent with the existence of ports of entry jobs into the establishment (Lazear and Oyer 2004) and highlights the role of firm-specific human capital as a determinant of internal transfers. Nonetheless, we also observe that a nontrivial proportion of vacancies at every level are filled by external hires, suggesting that firms' hiring strategies are complex and don't follow a strict policy of hiring from outside exclusively into a limited set of levels and from inside into others. For example, even at the two highest hierarchical levels $16 \%$ to $19 \%$ of the workers are externally hired, which suggests that there is some level of fluidity.

Internal hiring also varies with the firm and the establishment's size. The proportion of internal hires from establishments that remain open (Type I) decreases with the new establishment's size. Regarding firm size, we see that the proportion of internal hires seems to be higher for establishments that are affiliated with parent firms with less than 50 workers and with parent firms with more than 100 workers. Internal hiring also varies with the establishment's sector of activity. Internal hiring (both type I and Type II transfers) prevails in cae B (fishing), cae F (construction) and cae I (transport, storage and communication) and internal hiring from establishments that remain active (Type I transfers) prevail in cae I (transport, storage and communication), in cae B (fishing) and in cae $\mathrm{E}$ (electricity, gas and water supply). ${ }^{12}$

\footnotetext{
${ }^{10}$ Equivalent to the International Standard Classification of Occupations (ISCO): see Appendix C.

${ }^{11}$ For further details you may check the table in Appendix C.
}

Observing the 1,99,058 workers in our sample, employees that work in the newly created establishments, ${ }^{13}$ we notice that internally hired workers are older than average while individuals that are hired in the external labor market, particularly those that were out of the data set in the previous year, are younger indicating that some of these individuals may be starting their way in the labor market. The majority of internal hires have more than 36 months of tenure. Internal hires have a higher proportion of males while external hires have a predominance of females. When compared to external hires we find that internally hired individuals have a slightly higher proportion of workers with tertiary education. ${ }^{14}$ We also observe a lower proportion of top and middle managers in the group of externally hired individuals and a higher proportion of top hierarchical levels in the group of internal workers. Non-skilled professionals and apprentices are predominant in the group of externally hired workers. Frequently, these new establishments are smaller branches of the parent firm and so it is not surprising that, overall top executives only represent $5.3 \%$ of the workforce and over $70 \%$ of the hired workers are merely skilled or less than skilled professionals. ${ }^{15}$

\subsection{Establishment's survival statistics}

We find that $22 \%$ of the newly created establishments have closed after one year, allowing us to conclude that we have a relatively high death rate in the first year after the opening. In the 2 years that follow, the closure rate drops. As we can see in the Kaplan-Meier survival plot

\footnotetext{
${ }^{12}$ For more detailed data see Appendix E.

${ }^{13}$ We performed consistency checks on the panel. If we found an inconsistency in the variables gender, age, or tenure this was repaired, if possible; otherwise, the worker was removed from the sample (deleted observations represent less than $1 \%$ ).

${ }^{14}$ In this item, uncertain origin hires stand out because of the considerably higher proportion of more educated workers when compared with the other groups of individuals. We observe that more than half of these workers have 12 or more years of schooling. This might be consistent with a stronger bargain power of these workers allowing them to secure tenure.

${ }^{15}$ For more detailed data see Appendix F.
} 


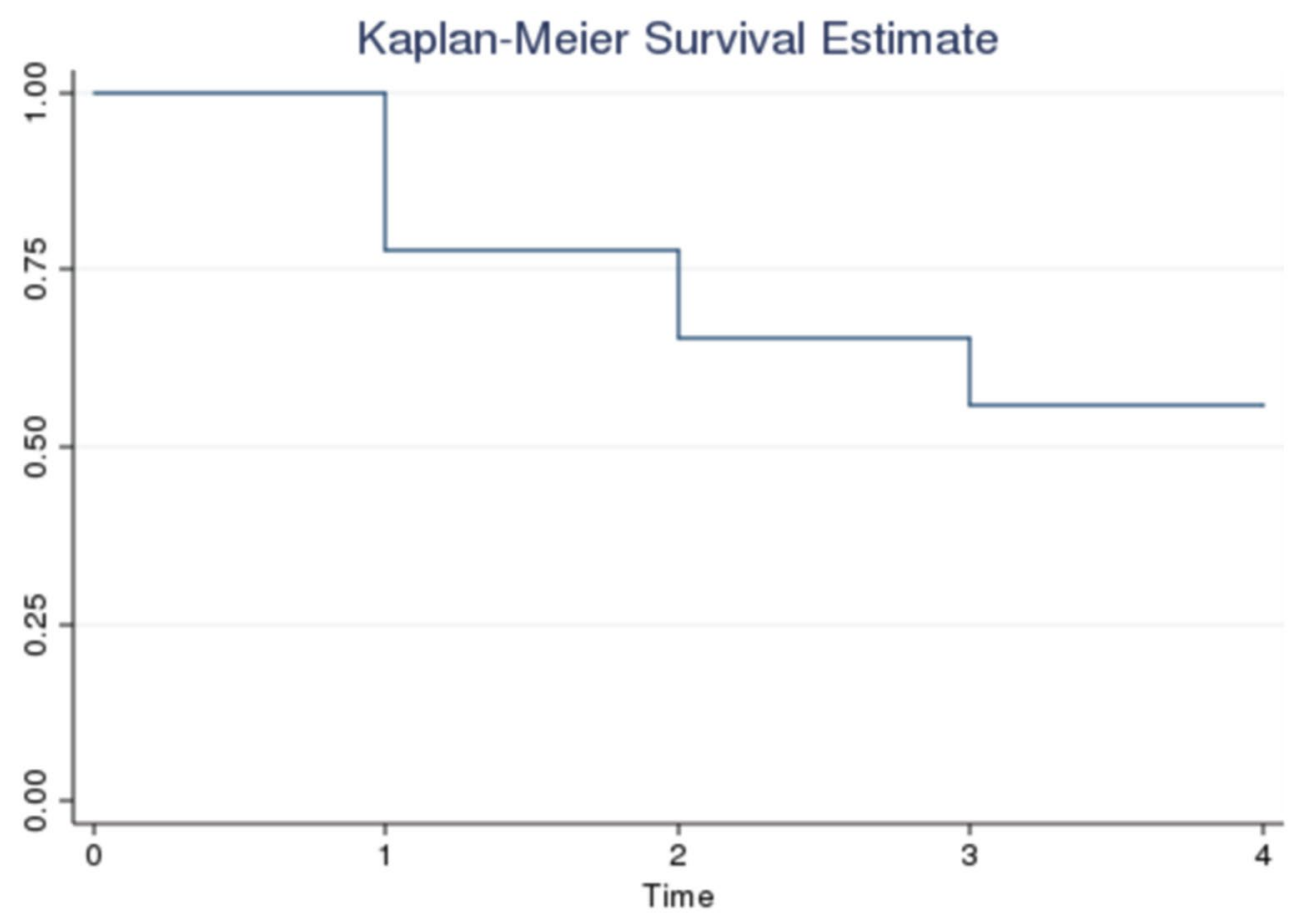

Fig. 3 Kaplan-Meier survival estimate

depicted in Fig. 3, 3 years after the opening $44 \%$ of the new establishments have closed (from the 24,163 new establishments, 13,397 remain open).

\section{Empirical methodology: duration models, unobserved heterogeneity and shared frailty models}

In order to analyze the new plant's survival we define a duration variable that measures the time elapsed since opening. The new establishments in our sample are followed until closure or for 3 years after the opening, hence, right censoring exists and is accommodated. We estimate duration models with time-invariant covariates as we are interested in analyzing how the plant's initial recruitment strategies affect the new unit's short term survival.

We acknowledge that the decision to transfer workers to the new establishment raises selectivity issues that, if ignored, lead to biased estimates. For internal hires, selection may occur for two reasons. First, employers choose which employee is offered the opportunity to move to the new establishment. Then, the transfer will only be observed if the worker accepts the opportunity he/she is offered. Both decisions are determined by the expected gains arising from the expected increase in the value of the match, i.e., internal transfers are the result of administrative selection and self-selection. This selectivity issues might themselves affect the establishment's survival. We estimate duration models with both firm-specific and establishment-specific controls. The former include the parent firm's growth, employment, number of plants and age and are included to control for the effect of observed characteristics that are shared by the newly created establishments affiliated with the same parent firm. The latter are the establishment's size and workforce structure (age, education, gender, hierarchical level and proportion of workers that are shared by the new establishment and other establishments of the same parent firm). The spatial dimension is also relevant in this context, as monitoring costs, information asymmetries and the share of internal transfer may depend on the distance to headquarters and other branches (Kalnins and Lafontaine 2013; Charnoz et al. 2018). To account for this spatial dimension, we also control for the distance from the new unit to the headquarters and the presence of other branches in the region where the new establishment is created. Notwithstanding the covariates included, there may still exist various factors that are unobservable to the researcher and that might affect the new unit's survival.

To account for selection on the unobservables, we estimate a frailty model, introducing a random parameter into the hazard rate that accounts for the 
Table 7 Parent firm characterization by number of establishments created, 2003-2005

\begin{tabular}{lc}
\hline Number of new estab. opened & Number of firms \\
\hline 1 & 7479 \\
2 to 9 & 3174 \\
10 to 19 & 143 \\
20 to 49 & 78 \\
More than 50 & 24 \\
\hline
\end{tabular}

unobserved heterogeneity (Chamberlain 1985). ${ }^{16}$ Not taking into account unobserved heterogeneity in duration models is particularly serious as it exacerbates negative duration dependence. This happens because, over time, as the frail units fail, the sample becomes populated by more and more robust individuals. As a consequence, the population hazards decline over time regardless of the shape of hazards that individuals face (Lancaster 1990).

Frailty models can account for frailties that are individual specific or frailties that are group-specific. To test the inclusion of establishment-specific frailty, we estimated a duration model with individual frailty including the above mentioned covariates and tested the hypotheses that $\theta$ (the variance of the frailty term present in the hazard model) is equal to zero. The likelihood ratio test didn't reject the hypotheses of $\theta$ being equal to zero, reducing the model to the standard survival function. Group unobserved heterogeneity arrises because the observations within a subgroup share unmeasured risk factors that may prompt them to exit earlier than other subgroups. This kind of frailty may exist for new establishments affiliated with the same parent firm as they share a common family background that might affect their survival. Likewise, it's reasonable to believe that units affiliated with different firms face different risks of closure.

We observe that several plants in our sample are affiliated with the same parent firm, as one firm may open several new units within the observed period (20032005). In Table 7 we see that 7479 firms open only one establishment but 3419 firms open more then one new unit.

Some of the characteristics that prompt a new establishments affiliated with one parent firm to be more (or less) prone to failure are directly accounted for in our duration model while others may be unobservable or

\footnotetext{
${ }^{16}$ Frailty models account for unobserved heterogeneity given the assumptions imposed by the model. For a discussion about the assumptions and limitation of these models please see Xue and Brookmeyer (1996), Clayton and Cuzick (1985), Hougaard (1986), Elbers and Ridder (1982).
}

unmeasurable. The shared frailty models assume that similar observations share a frailty that causes observations within the same group to be correlated, even though frailty may vary from group to group. To check for the appropriateness of introducing shared frailty in our model, we analyze the results from the likelihood ratio test of $H_{0}: \theta=0$. The result of the test indicates a statistically significant level of unobserved heterogeneity since the obtained $p$-value is virtually zero. We follow by briefly presenting the shared frailty models and how they relate to the individual frailty models.

The hazard function approximates the probability of closing within a short interval, conditional on having survived up to the starting time of the interval, that is:

$$
h(t)=\lim _{\Delta t \rightarrow 0} \frac{P(t \leq T<t+\Delta t \mid T \geq t)}{\Delta t}=\frac{f(t)}{1-F(t)}=\frac{f(t)}{S(t)}
$$

where $f(t)$ is the probability density function, $F(t)$ is the distribution function and $S(t)$ is the survival function.

If we integrate the hazard function we obtain:

$$
\Lambda(t)=\int_{0}^{t} h(u) d u
$$

which relates to the survival function simply by:

$$
S(t)=\exp \left(-\int_{0}^{t} h(u)\right)=\exp (-\Lambda(t)) .
$$

An particularly important class of models with timeinvariant regressors is the proportional hazard model that can be written as:

$$
h_{j}(t)=h_{0}(t) e^{X_{j} \beta}
$$

Now, suppose we have a sample of $j$ observations where some units are more prone than others to fail due to unobserved heterogeneity. If we have unobserved frailties, the hazard rate will be a function not only of the covariates but also of the frailties:

$$
h_{j}(t)=h_{0}(t) e^{\left(X_{j} \beta+W_{j} \psi\right)}
$$

where $W_{j}$ is a frailty term drawn from a probability distribution with a mean of 0 and a variance of 1 . If $\psi=0$, the standard proportional hazard model is obtained. ${ }^{17} \mathrm{We}$ can rewrite the hazard in the following form:

$$
h_{j}(t)=h_{0}(t) v_{j} e^{X_{j} \beta} \quad \text { where } v_{j}=e^{W_{j} \psi} .
$$

\footnotetext{
${ }^{17}$ Also, if we could measure/observe and directly include $W_{j}$ in our model, then $\psi$ would again go to 0 .
} 
The hazard rate is now conditional on both the covariates, $X$, and the frailty term, $v$. For identification purposes, we assume that the mean of $v$ is 1 and that the variance is unknown and equal to the parameter $\theta$.

If the hazard is a function of the frailties, then the survival function is also conditional on both the covariates and the frailty term. Thus, we have the conditional survival function (Lancaster 1990) as:

$$
S(t, X, v)=\exp \left(-\int_{0}^{t} h(u \mid v) d u\right)=\exp \left(-v \int_{0}^{t} h(u) d u\right)
$$

To derive the expected value of the survival function, we need to specify $g(v)$, a probability distribution for $v^{18}$ With the adoption of a distribution $g(v)$, the expected survival function is derived from the hazard rate:

$$
\begin{aligned}
S(t) & =E[S(t, X, v)]=E\left[\exp \left(-v \int_{0}^{t} h(u) d u\right)\right] \\
& =L\left[\exp \left(\int_{0}^{t} h(u) d u\right)\right]
\end{aligned}
$$

where $L$ is the Laplace transformation. This function is commonly referred to as the marginal survival function. Once the frailty is integrated out, accounting for unobserved heterogeneity is reduced to estimating $\theta$, the variance of the frailty term.

For empirical purposes, we will consider a Weibull frailty model, so the conditional survival function is:

$$
S(t \mid v)=e^{-(v \lambda t)^{\rho}}
$$

Additionally, we will assume a gamma distribution for $g(v)$. With gamma frailty, the marginal Weibull survival function is:

$$
S(t)=\left[1+\theta(\lambda t)^{\rho}\right]^{-\frac{1}{\theta}}
$$

and the hazard rate is now: ${ }^{19}$

$$
h(t)=\rho \lambda^{\rho} t^{\rho-1}[S(t)]^{\theta}
$$

The main difference between shared and unshared frailty models is the assumption about how the frailty is distributed in the data as the frailty is now group-specific. Suppose we have $j$ observations (new establishments) and $i$ subgroups (parent firms). The hazard rate for the $j$ th individual in the $i$ th subgroup is:

\footnotetext{
${ }^{18}$ The gamma distribution is the most commonly used in the literature.

19 When the variance of the frailty $\theta$ is 0 , the model reduces to the standard Weibull model.
}

$$
h_{i j}(t)=h_{0}(t) e^{X_{i j} \beta+W_{i} \psi}
$$

where $W_{i}$ is the subgroup frailty that the $j$ units share. The frailty is assumed to be independently distributed with a mean of 0 and a variance of $1 .{ }^{20}$ The hazard can be rewritten as:

$$
h_{i j}(t)=h_{0}(t) v_{i} e^{X_{i j} \beta} \quad \text { where } v_{i}=e^{W_{i} \psi} .
$$

The only difference from the individual frailty models is that frailty is now shared among the $j$ establishments of the $i$ th parent firm. To estimate the shared frailty model we just need to proceed exactly as in the case of individual heterogeneity, making the assumptions about $g(v)$.

Accounting for firm-specific frailty, in the following section, we discuss the results for the shared frailty model.

\subsection{Estimation and results}

Estimation results are summarized in Table 8. All the estimated regressions report the hazard ratios, include a set of time, industry and region dummies and controls for workers' hierarchical levels. A detailed description of the included covariates can be found in Appendix D. In the first estimation we report a standard Weibull duration model that controls only for observed (individual and shared) heterogeneity. In the second model we report results for a shared frailty model that also controls for unobserved heterogeneity shared between new units that are affiliated with the same parent firm, considering a gamma distribution for the shared frailty. ${ }^{21}$ In the third specification, we also report a shared frailty model but we add a control for the proportion of internal transfers at the plant's top hierarchical level. We stress that we include a control for the proportion of internal hires at the plant's highest hierarchical level and not the proportion of hires for "top executives", the highest hierarchical level in the data. This choice stems from the observation that most of these new units are small branches of the parent firm, that often don't have top managers in their personnel. However, even in small units, the transfer of firm-specific knowledge plays an important role and it's likely that this task is mainly carried out by workers with leadership roles that occupy the plant's highest hierarchical level. Therefore, to capture the importance of top level workers in knowledge transfer but also to account for the establishments' personnel structure, we identified

\footnotetext{
${ }^{20}$ Again, if $\psi=0$ or if we could directly observe and include $W_{i}$, the standard proportional hazards model is obtained.

21 As a robustness check we also estimated the model considering an inverse-Gaussian distribution for the shared frailty and obtained similar results.
} 
Table 8 Duration model and shared frailty model: 2003-2008

\begin{tabular}{|c|c|c|c|c|c|c|}
\hline \multirow[t]{2}{*}{ Variables } & \multicolumn{2}{|c|}{ Duration model } & \multicolumn{2}{|c|}{ Shared frailty I } & \multicolumn{2}{|c|}{ Shared frailty II } \\
\hline & Haz. ratio & t-ratio & Haz. ratio & t-ratio & Haz. ratio & t-ratio \\
\hline \% Internal (Type I) & $0.7783^{* * *}$ & $(-8.15)$ & $0.7952^{* * *}$ & $(-5.41)$ & 0.9664 & $(-0.42)$ \\
\hline \% Internal (Type II) & 1.0250 & $(0.80)$ & $0.8431^{* * *}$ & $(-4.04)$ & $0.8379^{* * *}$ & $(-4.18)$ \\
\hline \% Uncertain Origin & $0.6484^{* * *}$ & $(-7.33)$ & 0.9275 & $(-0.86)$ & 0.9211 & $(-0.94)$ \\
\hline \% Internal (I): Top level & & & & & $0.8239^{* * *}$ & $(-2.76)$ \\
\hline Plant size & $0.8244^{* * *}$ & $(-17.27)$ & $0.7661^{* * *}$ & $(-18.06)$ & $0.7685^{* * *}$ & $(-17.79)$ \\
\hline Distance & 0.9998 & $(-0.62)$ & 0.9999 & $(-0.38)$ & 0.9999 & $(-0.37)$ \\
\hline Est. Concent. & $0.7929 * * *$ & $(-5.53)$ & $0.8486^{* *}$ & $(-2.46)$ & $0.8504^{* *}$ & $(-2.43)$ \\
\hline Plant: \% 25 to 34 & $1.1059^{*}$ & $(2.44)$ & $1.0915^{*}$ & $(1.66)$ & 1.0897 & $(1.63)$ \\
\hline Plant: \% 34 to 54 & $1.0952^{* *}$ & $(2.25)$ & $1.1004^{*}$ & $(1.74)$ & $1.0987^{*}$ & $(1.72)$ \\
\hline Plant: \% + 54 & 1.0360 & $(0.56)$ & $1.1521^{*}$ & $(1.65)$ & 1.1477 & $(1.61)$ \\
\hline Plant: \% Educ 9 & 0.9527 & $(-1.46)$ & 0.9961 & $(-0.08)$ & 0.9981 & $(-0.05)$ \\
\hline Plant: \% Educ 12 & $0.8639^{* * *}$ & $(-4.25)$ & 0.9263 & $(-1.55)$ & 0.9275 & $(-1.53)$ \\
\hline Plant: \% Educ + 12 & $0.8680^{* *}$ & $(-2.58)$ & 1.0440 & $(-0.56)$ & 1.0415 & $(-0.53)$ \\
\hline Plant \% Female & $0.8960^{* * *}$ & $(-4.18)$ & 0.9387 & $(-1.60)$ & 0.9383 & $(-1.61)$ \\
\hline Plant \% Shared & $1.6377^{* * *}$ & (3.03) & $1.8461^{* *}$ & $(2.44)$ & $1.8527^{* *}$ & $(2.46)$ \\
\hline Firm growth & $0.8426^{* * *}$ & $(-7.18)$ & $0.9262^{*}$ & $(-2.17)$ & $0.9260^{* *}$ & $(-2.18)$ \\
\hline Firm size & $0.9227^{* * *}$ & $(-9.59)$ & $0.9111^{* * *}$ & $(-5.09)$ & $0.9115^{* * *}$ & $(-5.06)$ \\
\hline Multi-plant firm & $1.0431^{* *}$ & $(1.74)$ & 0.9578 & $(-1.05)$ & 0.9589 & $(-1.02)$ \\
\hline Firm age & 0.9999 & $(-0.52)$ & 1.0002 & $(0.87)$ & 1.0001 & $(0.88)$ \\
\hline Constant & $0.1067^{* * *}$ & $(-18.72)$ & $0.1134^{* * *}$ & $(-11.53)$ & $0.1136^{* * *}$ & $(-11.52)$ \\
\hline N & 24,163 & & 24,163 & & 24,163 & \\
\hline$\rho$ & 1.3232 & & 1.8215 & & 1.8216 & \\
\hline$\theta$ & & & 1.9591 & & 1.9571 & \\
\hline Log likelihood & -24677.94 & & -22464.68 & & -22460.85 & \\
\hline Prob $>x^{2}$ & 0.0000 & & 0.0000 & & 0.0000 & \\
\hline
\end{tabular}

Specifications include time, industry and region dummies and controls for worker's hierarchical level

$* * *, * *,{ }^{*}$ denotes statistically significant at $1 \%, 5 \%$, and $10 \%$, respectively

the highest hierarchical level present in each new establishment and included a control for the proportion of internal hires in this highest level.

Analyzing the first specification, that disregards unobserved heterogeneity, we see that the Weibull hazard function exhibits a positive duration dependence as the estimated $\rho$ parameter is greater than 1 , meaning that the new plant's hazard of failure increases over time. However, as discussed in the previous section, if unobserved frailty exists this estimate is likely to be biased downwards as the frailty pushes down the duration dependence. Indeed, in the shared frailty model, reported in the second column, we can observe an increase in the parameter $\rho$.

With frailty models, we can distinguish between the hazard rates that individuals face and the population hazard. In a standard proportional hazard model, these hazards are the same since all individuals are assumed to be identical. However, in a heterogeneous population, with group-shared frailty the population hazard can fall while the individual hazards rise because, over time, as the frail members close, the population becomes crowded by more and more robust individuals. This frailty effect assures that population hazards may decline over time regardless of the shape of hazards that individuals face. Considering the gamma shared frailty model reported in the second column of Table 8, we show in Fig. 4 the population (or unconditional) hazard, while the mean individual (or conditional) hazard is shown in Fig. 5. Indeed, we observe that the population hazard does decline after the second year whereas the individual hazard continues to climb.

Examining the results for the shared frailty models, we also observe that new plants affiliated with growing 


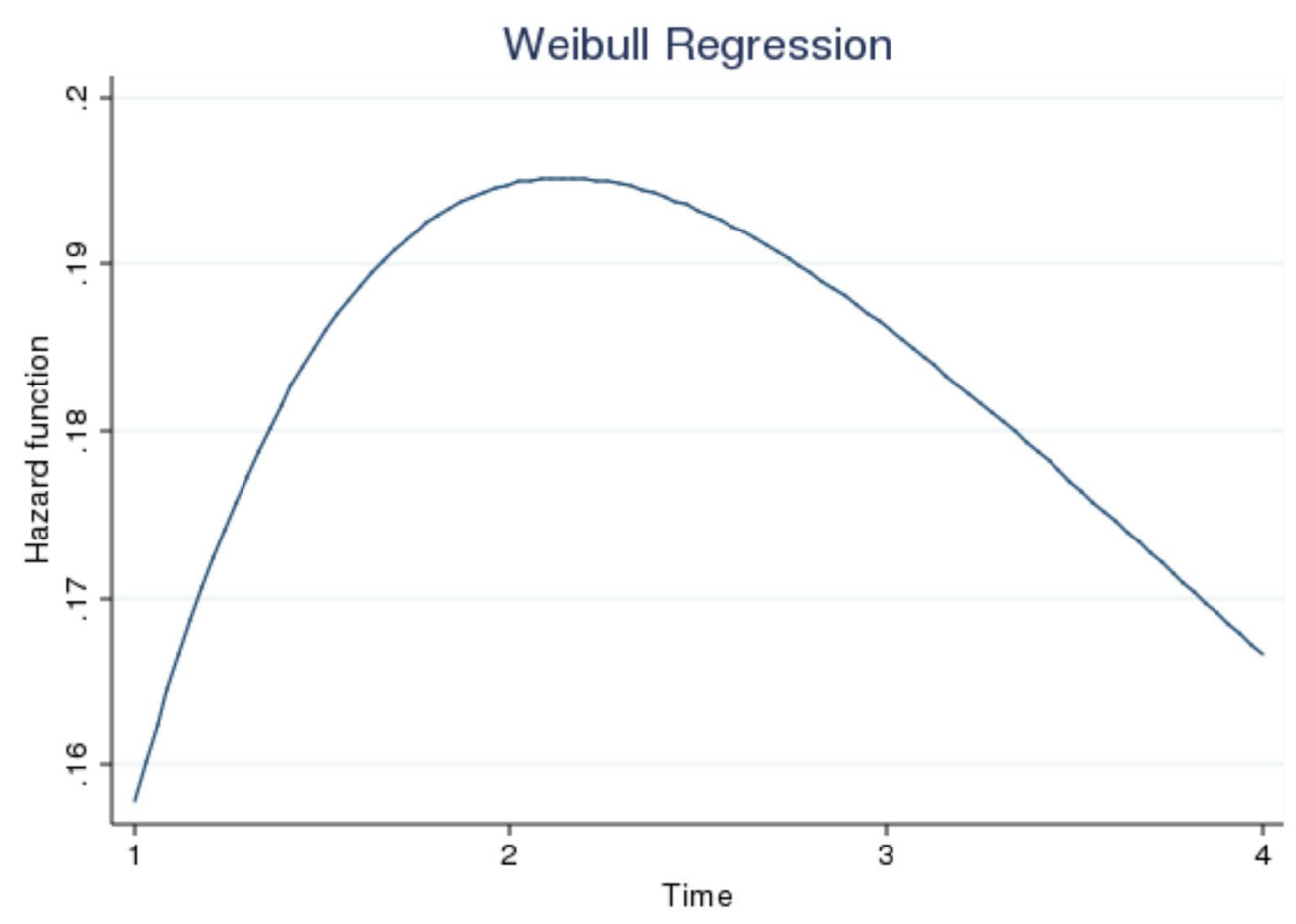

Fig. 4 Population/unconditional hazard

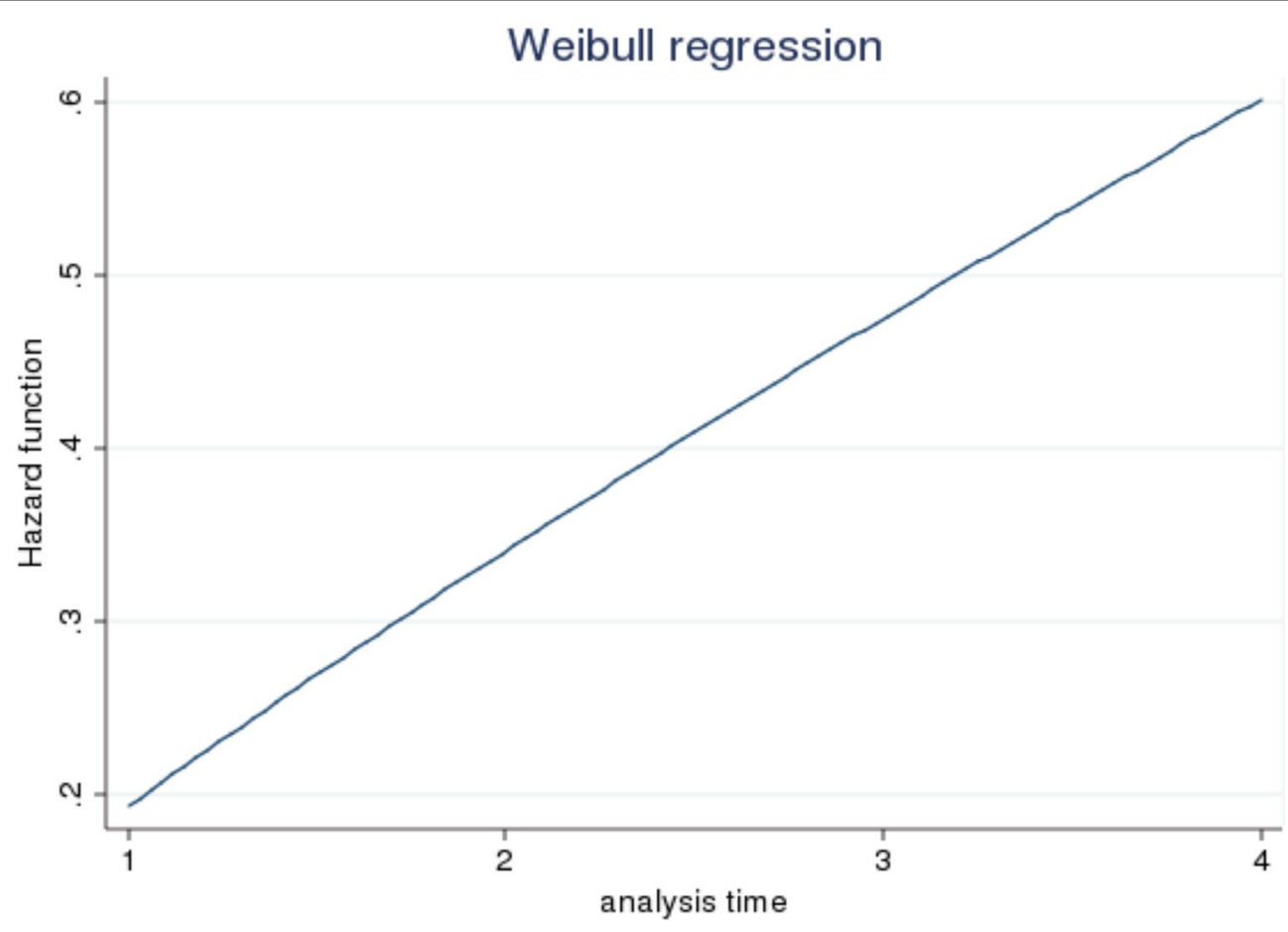

Fig. 5 Individual/conditional hazard 
firms are less likely to close. ${ }^{22}$ New establishments affiliated with large firms also tend to be less prone to failure. Therefore, we may conclude that being linked to a large growing parent firm apparently increases the robustness of the new unit and provides a favorable environment for the new establishment. The parent firms' age and being a multi-establishment firm before the opening of the new unit don't appear to have a statistically significant impact on the new unit's closure probability. Analyzing how new plants' characteristics affect failure, we conclude that larger establishments have a decrease in the risk of closure of $23 \%$. Previous studies on firm duration have concluded that the probability of failure is negatively related to firm size (Mata and Portugal 1994). Larger units should be able to survive longer because, when facing negative outcomes, they have the option to shrink before they exit. On the other hand, larger entry size may signal greater a priori expectations of success and more periods with bad results will be needed to eliminate the ex ante positive expectations (Frank 1988). Larger units may also take longer to fail as small units tend to be more flexible and respond more easily to market fluctuations (Mills and Schumann 1985). Looking at the composition of the new plant's personnel, we observe that plants with a higher proportion of young workers tend to fail less. Furthermore, new establishments with a higher proportion of more educated workers and with a higher proportion of skilled workers (i.e., workers in managerial and technical occupations) seem to have a lower probability of failing, although some of the regressors are not statistically significant. ${ }^{23}$ We also conclude that the presence of a higher proportion of employees that the new plant has to share with other establishments of the parent firm increases the new unit's risk of failure, as less time is dedicated by these workers to the new unit. The distance to the headquarters doesn't have a statistically significant impact in the new units survival. The existence of other branches in the same region where the establishment is created, reduces the risk of closure by around 15\%, for both shared frailty specifications.

In order to discuss the relevance of firm-specific human capital, we assess how the firm's recruitment strategy in the internal versus external labor market affects survival. Considering the shared frailty model in the second column of Table 8, we observe that a higher proportion of total internal hires, compared to external hires, decreases the probability of failing. This positive impact on the new

\footnotetext{
${ }^{22}$ To avoid endogeneity problems related to the impact on the firm's growth due to the opening of the new unit, our growth dummy controls for the increase in the total number of workers employed by the firm not including the new unit's employees.

${ }^{23}$ Previous works have concluded that the larger the initial stock of human capital in the firm, the lower the likelihood that the firm will exit (Geroski et al. 2010).
}

establishment's survival is obtained for both types of internal hires, whether they come from establishments that remain in operation (Type I transfers) whether they come from establishments that are closing (Type II transfer). For establishments with Type I transfers there is a reduction in the risk of closure of $20 \%$ and for Type II transfers this reduction is around $16 \%$. This evidence supports our hypothesis that embodied firm-specific human capital plays an important role in improving the survival of newly created establishments.

However, not all employees are equally important in the process of knowledge transfer. To get a more detailed outlook on how this channel works, in the specification reported in column three of Table 8 , we add a control for the proportion of internal hires at the new establishment's top hierarchical level. Adding this control, we observe that the proportion of internal transfers at the highest hierarchical level reduces the risk of closure by $18 \%$ but, we also note that the total proportion of Type I internal hires loses its statistical significance. We may conclude that the internal hire of skilled workers at high-rank jobs is crucial to the new plant's survival, corroborating the hypothesis that the transmission of firm-specific human capital is mainly carried out by these workers while lower skilled, undifferentiated workers will not play such an important role in the knowledge transfer process. In the new plant, skilled workers will be responsible for the diffusion of firmspecific human capital that will positively affect the new establishment's survival. We conclude that, although some knowledge is tacit and hard to codify it can be successfully transferred from the parent firm to the new unit embodied in the group of employees that are internally transferred. Internal transfers are likely to be one of the most important channels to share and transfer this "unique" asset to the new plant. Moreover, the positive impact on the firm's survival generated by the proportion of internal hires at higher skilled positions corroborates the finding that workers internally hired to higher-rank jobs are more likely to have been chosen on the basis of their ability, as Chan (1996) pointed out.

\section{Conclusion}

In this paper we examined the survival of new plants affiliated with pre-established firms. Entrants from preestablished firms deserve special and separated attention as the determinants of survival may differ. A central issue in entries by pre-established firms is that the parent firm can supply expertise in management and operational knowledge which may aid the new plant developing a successful entry strategy. Our work builds upon the study of the channels by which the parent firm or other establishments in the same group transfer expertise to the newly opened branch by suggesting a direct channel for 
knowledge transfer that has been little addressed in previous literature: the internal transfer of employees from pre-existing units to the new establishment. Our hypothesis is that within-firm and across establishments mobility plays a central role in the transfer of firm-specific knowledge and, therefore, positively affects survival.

We observed that internal hires are an important way to fill the new vacancies created by the opening of a new establishment. On average, more than half of the workers in the new plant are hired from other establishments of the same firm. Although some of these employees were transferred from establishments that closed, we also found that the proportion of internal hires that were transferred from establishments that remain in operation was still high, reaching $30 \%$, and this proportion increases to around $40 \%$ for the highest hierarchical levels and skilled workers. Among the reasons that can explain the option for internal hires, we believe that, for new entrants, the need to transfer firm-specific human capital to the new unit is a key argument. Indeed, we observed that almost $70 \%$ of the internally hired workers had more than 36 months of tenure at the firm. The specific knowledge argument is also particularly pertinent for skilled workers and we observed that internal hires prevail at higher levels and for skilled professionals. Overall, external labor market hires seemed to prevail for occupations that were closer to the bottom of the hierarchy, giving some support for the existence of ports of entry. Nevertheless, we also observed that firm's recruitment strategies are complex and external hires may be observed virtually at all levels and, even for the two highest hierarchical levels, $16 \%$ to $19 \%$ of the jobs were filled externally.

Duration models were used to analyze the impact of internal hiring on survival. Given that, new plants affiliated with the same parent firm share the same family background, we included shared frailty in our analysis to account for different risks of closure of establishments affiliated with different firms. The obtained results strongly supported the presence of shared unobserved heterogeneity that affects the new plant's survival.

We observed that the proportion of internal hires has a positive impact on survival. The obtained results led us to conclude that internal transfers are, probably, one important channel to transfer firm-specific knowledge to the new establishments. This non-tradable unique asset may create an important competitive advantage for new units affiliated with pre-established firms. We also concluded that not all types of employees are equally important to this process of knowledge transfer. Low skilled workers are not at the centre of strategic decisions and, therefore, are not critical for a successful expertise transfer. The transfer of firm-specific expertise is carried out by the skilled workers that are internally hired to the new establishment's top-level jobs. Finally, the improved survival of establishments with a higher proportion of skilled internal hires also supports the premise that at higher levels, hires are based on the candidates' superior ability. Our main conclusion is that firm-specific knowledge, that is an important source of competitive advantage and that can improve the new plant's survival, can be successfully transferred from the parent firm to the new unit embodied in the group of employees that are internally transferred.

Finally, bearing in mind our finding that a significant proportion of vacancies in the new plant are filled by employees transferred from other establishments of the same firm that remain open, we believe that promising future research in this field could focus on what happens at the origin when these workers are transferred to the new plant. Namely, it would be relevant to assess how the establishment of origin copes with the exit when an employee is transferred to a new establishment.

\begin{abstract}
Acknowledgements
The author acknowledges the Portuguese Ministry of Labor, Solidarity, and Social Security, Department Statistics (GEP), for granting access to the data for this research. The author thanks, Anabela Carneiro, José Varej ão, Liliana Fernandes and an anonymous referee for the comments.
\end{abstract}

\section{Authors' contributions}

This is an original article from the author. The author read and approved the final manuscript.

\section{Data availability statement}

The data set in this study uses Quadros de Pessoal (QP; Personnel Records), a matched employer-employee data set. $Q P$ is an annual mandatory employment survey collected by the Portuguese Ministry of Labor, Solidarity, and Social Security. The data is available for all researchers, although a request has to be sent to the Portuguese Ministry.

Competing interests

The author assures that there are no competing interests to be mentioned.

\section{Appendix A}

Hierarchical levels defined by law (Decreto-Lei no. 121/78, de 2 Junho):

\begin{tabular}{ll}
\hline Level & Description \\
\hline Level 1 & Top executives (top management) \\
Level 2 & $\begin{array}{c}\text { Intermediary executives (middle } \\
\text { management) }\end{array}$ \\
Level 3 & Supervisors, team leaders, foremen \\
Level 4 & Higher-skilled professionals \\
Level 5 & Skilled professionals \\
Level 6 & Semi-skilled professionals \\
Level 7 & Non-skilled professionals \\
Level 8 & Apprentices, interns, trainees
\end{tabular}




\section{Appendix B}

CAE-Portuguese Classification of Economic Activities (cae), equivalent to SIC codes:

\begin{tabular}{ll}
\hline cae & Description \\
\hline cae A & Agriculture, animal husbandry, hunting and forestry \\
cae B & Fishing \\
cae C & Mining and quarrying \\
cae D & Manufacturing \\
cae E & Electricity, gas and water supply \\
cae F & Construction \\
cae G & Wholesale and retail trade \\
cae H & Hotels and restaurants \\
cae I & Transport, storage and communication \\
cae J & Financial activities \\
cae K & Real estate, renting and business activities \\
cae L & Public Administration, Community, Social and Personal Services ${ }^{\text {a }}$ \\
cae M & Education \\
cae N & Health and social work \\
cae O & Other community, social and personal service activities \\
cae P & Families with household employee \\
cae Q & International Institutions and other extra-territorial organizations
\end{tabular}

a Establishments belonging to CAE L were dropped as this sector is out of the main scope of our analysis (this establishments represented less than $1 \%$ of the initial group)

\section{Appendix C}

National classification of occupations (NCO), equivalent to the International Standard Classification of Occupations (ISCO):

\begin{tabular}{ll}
\hline NCO & Description \\
\hline NCO 1 & Executive civil servants, industrial directors and executives \\
NCO 2 & Professionals and scientists \\
NCO 3 & Middle management and technicians \\
NCO 4 & Administrative and related workers \\
NCO 5 & Service and sales workers \\
NCO 6 & Farmers and skilled agricultural and fisheries workers \\
NCO 7 & Skilled workers, craftsmen and similar \\
NCO 8 & Machine operators and assembly workers \\
NCO 9 & Unskilled workers \\
\hline
\end{tabular}

Type of hiring by NCO: 2003-2005

\begin{tabular}{|c|c|c|c|c|c|c|c|c|c|}
\hline Type of hiring & NCO1 & $\mathrm{NCO} 2$ & $\mathrm{NCO} 3$ & NCO4 & NCO5 & NCO6 & NCO7 & NCO8 & NCO9 \\
\hline Internal (total) (\%) & 76.8 & 68.3 & 55.3 & 55.6 & 43.2 & 53.3 & 64.3 & 64.8 & 51.2 \\
\hline Internal: Type I (\%) & 42.9 & 36.5 & 29.3 & 31.2 & 23.4 & 25.0 & 30.3 & 31.1 & 25.7 \\
\hline Internal: Type II (\%) & 33.9 & 31.8 & 26.0 & 24.4 & 19.8 & 28.3 & 34.0 & 33.7 & 25.5 \\
\hline $\begin{array}{l}\text { External: outside } \\
\text { QP (\%) }\end{array}$ & 7.2 & 15.4 & 13.0 & 18.5 & 34.3 & 22.0 & 17.5 & 15.9 & 27.7 \\
\hline $\begin{array}{l}\text { External: other firm } \\
(\%)\end{array}$ & 8.2 & 11.5 & 11.9 & 11.9 & 18.0 & 16.9 & 12.5 & 12.6 & 15.2 \\
\hline $\begin{array}{l}\text { Uncertain origin } \\
\text { (\%) }\end{array}$ & 7.8 & 4.8 & 19.8 & 14.0 & 4.5 & 7.8 & 5.7 & 6.7 & 5.9 \\
\hline Number of estab. & 3500 & 2227 & 6574 & 9578 & 9654 & 355 & 3684 & 2216 & 4717 \\
\hline
\end{tabular}




\section{Appendix D Variables description:}

\begin{tabular}{|c|c|}
\hline Variable & Description \\
\hline \% Internal (Type I) & $\begin{array}{l}\text { Percentage of workers transferred } \\
\text { from an establishment that } \\
\text { remains active (\% of total) }\end{array}$ \\
\hline \% Internal (Type II) & $\begin{array}{l}\text { Percentage of workers transferred } \\
\text { from an establishment that closed } \\
\text { (\% of total) }\end{array}$ \\
\hline \% Uncertain Origin & $\begin{array}{l}\text { Percentage of workers transferred } \\
\text { from an establishment that closed } \\
\text { (\% of total) }\end{array}$ \\
\hline \% Internal (I): Top level & $\begin{array}{l}\text { Percentage of workers transferred } \\
\text { from an establishment that } \\
\text { remains active (\% tot. at level) }\end{array}$ \\
\hline Plant size & $\begin{array}{l}\text { New establishment size (log num- } \\
\text { ber of workers) }\end{array}$ \\
\hline Plant: \% 25 to 34 & $\begin{array}{l}\text { Percentage of workers in the new } \\
\text { establishment between } 25 \text { and } 34 \\
\text { years (\% of total) }\end{array}$ \\
\hline Estab. concent & $\begin{array}{l}\text { Concentration of establishments of } \\
\text { the same parent firm in the region } \\
\text { (number of estab. in the region } \\
\text { divided by the total number of } \\
\text { estab.) }\end{array}$ \\
\hline Distance & $\begin{array}{l}\text { Distance (in } \mathrm{km} \text { ) from the capital of } \\
\text { the distrito where the estab. is cre- } \\
\text { ated to the capital of the distrito of } \\
\text { the headquarters }\end{array}$ \\
\hline Plant: \% 34 to 54 & $\begin{array}{l}\text { Percentage of workers in the new } \\
\text { establishment between } 34 \text { and } 54 \\
\text { years (\% of total) }\end{array}$ \\
\hline Plant: $\%+54$ & $\begin{array}{l}\text { Percentage of workers in the new } \\
\text { establishment with more than } 54 \\
\text { years (\% of total) }\end{array}$ \\
\hline Plant: \% Educ 9 & $\begin{array}{l}\text { Percentage of workers in the new } \\
\text { establishment with } 6 \text { or } 9 \text { years of } \\
\text { schooling completed }\end{array}$ \\
\hline Plant: \% Educ 12 & $\begin{array}{l}\text { Percentage of workers in the new } \\
\text { establishment with } 12 \text { years of } \\
\text { schooling completed }\end{array}$ \\
\hline Plant: \% Educ + 12 & $\begin{array}{l}\text { Percentage of workers in the new } \\
\text { establishment with more than } 12 \\
\text { years of schooling completed }\end{array}$ \\
\hline
\end{tabular}

Variables description (continuation):

\begin{tabular}{|c|c|}
\hline Variable & Description \\
\hline Plant \% female & Percentage of female workers in the new establishment \\
\hline Plant \% shared & $\begin{array}{l}\text { Percentage of workers in the new establishment shared } \\
\text { with other establishments }\end{array}$ \\
\hline Firm growth & $\begin{array}{l}\text { Dummy equal } 1 \text { if the number of workers in the firm } \\
\text { increase }\end{array}$ \\
\hline Firm size & Firm size (log number of workers) \\
\hline
\end{tabular}

\begin{tabular}{ll}
\hline Variable & Description \\
\hline $\begin{array}{ll}\text { Multi-plant firm } & \begin{array}{c}\text { Dummy equal } 1 \text { if the firm was multi-establishment } \\
\text { before the new opening }\end{array} \\
\text { Firm age } & \text { Age of the firm in years }\end{array}$ \\
\hline
\end{tabular}

\section{Appendix E \\ Characterizing new establishments: 2003-2005}

\begin{tabular}{ll}
\hline CAE (\%) & \\
A-Agriculture, animal husbandry, hunting and forestry & 1.4 \\
B-Fishing & 0.04 \\
C-Mining and quarrying & 0.3 \\
D-Manufacturing & 6.5 \\
E-Electricity, gas and water supply & 0.5 \\
F-Construction & 7.4 \\
G-Wholesale and retail trade & 40.0 \\
H-Hotels and restaurants & 7.5 \\
I-Transport, storage and communication & 6.0 \\
J-Financial activities & 10.1 \\
K-Real estate, renting and business activities & 11.1 \\
L-Public adm., community, social and personal serv. & - \\
M-Education & 0.9 \\
N-Health and social work & 4.1 \\
O-Other community, social and personal service act. & 4.2 \\
P-Families with household employee & - \\
Q-International inst. and other extra-territorial org. & - \\
Region (\%) & \\
Norte & \\
Centro & 27.0 \\
Lisboa & 21.3 \\
Alentejo & 30.7 \\
Algarve & 8.2 \\
Madeira & 6.0 \\
Açores & 3.2 \\
Foreign & 3.4 \\
\hline & \\
\hline
\end{tabular}

Type of hiring by size of the new establishment: 2003-2005

\begin{tabular}{lrll}
\hline Estab. Size & No Estab & $\begin{array}{l}\text { Internal } \\
\text { hiring } \\
(\%)\end{array}$ & $\begin{array}{l}\text { Internal: } \\
\text { Type I (\%) }\end{array}$ \\
\hline$<10$ workers & 20,395 & 51.3 & 29.6 \\
$10 \leq$ workers $<50$ & 3456 & 53.3 & 27.2 \\
$\geq 50$ workers & 541 & 59.3 & 27.1 \\
& 24,392 & & \\
\hline
\end{tabular}


Type of hiring by parent firm size: 2003-2005

\begin{tabular}{lcll}
\hline Firm Size & No Estab & $\begin{array}{l}\text { Internal } \\
\text { hiring } \\
\text { (\%) }\end{array}$ & $\begin{array}{l}\text { Internal: } \\
\text { Type I (\%) }\end{array}$ \\
\hline$<10$ workers & 6494 & 54.9 & 32.9 \\
$10 \leq$ workers $<50$ & 6932 & 51.2 & 28.2 \\
$50 \leq$ workers $<100$ & 2303 & 48.7 & 23.0 \\
$\geq 100$ workers & 8663 & 50.8 & 28.8 \\
& 24,392 & & \\
\hline
\end{tabular}

Type of hiring by economic activity: 2003-2005

\begin{tabular}{llll}
\hline CAE & $\mathbf{N}^{\mathbf{0}}$ Estab & Internal hiring (\%) & $\begin{array}{l}\text { Internal: } \\
\text { Type I } \\
\text { (\%) }\end{array}$ \\
\hline A & 333 & 57.1 & 27.6 \\
B & 10 & 79.2 & 48.3 \\
C & 69 & 66.1 & 39.2 \\
D & 1577 & 61.1 & 35.8 \\
E & 128 & 58.9 & 40.4 \\
F & 1814 & 73.9 & 29.5 \\
\hline
\end{tabular}

\begin{tabular}{llll}
\hline CAE & $\mathbf{N}^{\boldsymbol{0}}$ Estab & Internal hiring (\%) & $\begin{array}{l}\text { Internal: } \\
\text { Type I } \\
(\%)\end{array}$ \\
\hline $\mathrm{G}$ & 9756 & 46.0 & 25.7 \\
$\mathrm{H}$ & 1830 & 40.8 & 23.8 \\
$\mathrm{I}$ & 1469 & 73.4 & 59.3 \\
$\mathrm{~J}$ & 2473 & 45.7 & 25.7 \\
$\mathrm{~K}$ & 2696 & 45.6 & 25.0 \\
$\mathrm{~L}$ & 0 & - & - \\
$\mathrm{M}$ & 213 & 60.1 & 33.5 \\
$\mathrm{~N}$ & 1001 & 63.3 & 36.3 \\
$\mathrm{O}$ & 1023 & 56.5 & 27.0 \\
$\mathrm{P} / \mathrm{Q}$ & 0 & - & - \\
& 24,392 & & \\
\hline
\end{tabular}

\section{Appendix F}

Workers' characteristics by type of hire: 2003-2005

\begin{tabular}{|c|c|c|c|c|c|c|c|}
\hline & \multirow[t]{2}{*}{ All } & \multicolumn{3}{|l|}{ Internal } & \multicolumn{2}{|l|}{ External } & \multirow{2}{*}{$\begin{array}{l}\text { Uncertain } \\
\text { origin }\end{array}$} \\
\hline & & Total & Type I & Type II & Out QP & Other firm & \\
\hline Number of workers & $1,99,058$ & $1,11,506$ & 5,2275 & 59,231 & 42552 & 25,512 & 19,488 \\
\hline \multicolumn{8}{|l|}{ Age (\%) } \\
\hline Less than 25 years & 16.2 & 9.3 & 8.1 & 10.4 & 36.4 & 20.5 & 5.6 \\
\hline$[25,34]$ & 33.8 & 32.6 & 32.9 & 32.2 & 34.8 & 40.2 & 30.8 \\
\hline$[34,54]$ & 43.8 & 50.2 & 51.2 & 49.3 & 26.4 & 36.1 & 55.4 \\
\hline More than 54 years & 6.2 & 8.0 & 7.8 & 8.1 & 2.5 & 3.2 & 8.2 \\
\hline Female & 46.3 & 41.4 & 42.0 & 40.9 & 55.8 & 50.5 & 48.4 \\
\hline \multicolumn{8}{|l|}{ Tenure (\%) } \\
\hline Less than 12 months & 35.1 & 2.6 & 2.8 & 2.4 & 98.2 & 98.8 & - \\
\hline$[12,36]$ & 19.6 & 31.0 & 29.3 & 32.5 & 1.8 & 1.2 & 16.9 \\
\hline More than 36 months & 45.3 & 66.4 & 67.9 & 65.1 & - & - & 83.1 \\
\hline \multicolumn{8}{|l|}{ Education (\%) } \\
\hline Less than 9 years & 37.1 & 40.6 & 37.5 & 43.4 & 32.2 & 36.3 & 28.8 \\
\hline 9 years of schooling & 23.7 & 21.8 & 22.9 & 20.9 & 28.3 & 27.2 & 19.6 \\
\hline 12 years of schooling & 26.9 & 25.1 & 26.5 & 23.8 & 29.7 & 26.3 & 31.7 \\
\hline More than 12 years & 11.5 & 11.9 & 12.8 & 11.1 & 8.4 & 8.8 & 19.8 \\
\hline \multicolumn{8}{|l|}{ Hierarchical level (\%) } \\
\hline Top executives & 5.3 & 6.9 & 7.9 & 6.1 & 1.8 & 3.4 & 5.9 \\
\hline Intermed. executives & 4.3 & 5.3 & 6 & 4.7 & 1.4 & 2.7 & 7.3 \\
\hline Supervisors & 4.6 & 6.2 & 5.9 & 6.4 & 2 & 3.7 & 3.0 \\
\hline High-skilled prof. & 8.0 & 9.1 & 10.9 & 7.4 & 2.9 & 4.3 & 17.9 \\
\hline Skilled prof. & 35.6 & 37.2 & 34.4 & 39.7 & 29.1 & 34.9 & 41.6 \\
\hline
\end{tabular}




\begin{tabular}{|c|c|c|c|c|c|c|c|}
\hline & \multirow[t]{2}{*}{ All } & \multicolumn{3}{|c|}{ Internal } & \multicolumn{2}{|l|}{ External } & \multirow{2}{*}{$\begin{array}{l}\text { Uncertain } \\
\text { origin }\end{array}$} \\
\hline & & Total & Type I & Type II & Out QP & Other firm & \\
\hline Semi-skilled prof. & 15.1 & 15.9 & 19.9 & 12.2 & 16.2 & 15.4 & 7.9 \\
\hline Non-skilled prof. & 15.9 & 13.2 & 9.0 & 16.9 & 22.9 & 18.4 & 12.4 \\
\hline Apprentices & 4.9 & 2.3 & 2.3 & 2.3 & 11.5 & 7.0 & 2.3 \\
\hline
\end{tabular}

Received: 30 May 2019 Accepted: 13 January 2020

Published online: 04 February 2020

\section{References}

Audretsch, D., Mahmood, T.: The rate of hazard confronting new firms and plants in US manufacturing. Rev. Ind. Org. 9(1), 41-56 (1994)

Baker, G., Gibbs, M., Holmstrom, B.: The internal economics of the firm: evidence from personnel data. Q. J. Econ. 109(4), 881-919 (1994a)

Baker, G., Gibbs, M., Holmstrom, B.: The wage policy of a firm. Q. J. Econ. 109(4), 921-955 (1994b)

Barney, J.: Firm resources and sustained competitive advantage. J. Manag. 17(1), 99-120 (1991)

Becker, G.S.: Investment in human capital: a theoretical analysis. J. Polit. Econ. 70(5), 9-49 (1962)

Brito, P., Mello, A.: Financial constraints and firm post-entry performance. Int. J Ind. Org. 13(4), 543-566 (1995)

Chamberlain, G.: Heterogeneity, omitted variable bias, and duration dependence. In: Heckman, J., Singer, B. (eds.) Longitudinal analysis of labour market data, pp. 3-38. Cambridge University Press, Cambridge (1985)

Chan, W.: External recruitment versus internal promotion. J. Labor Econ. 14(4), 555-570 (1996)

Charnoz, Pauline, Lelarge, Claire, Trevien, Corentin: Communication costs and the internal organisation of multi-plant businesses: evidence from the impact of the French high-speed rail. Econ. J. 128, 949-994 (2018)

Clayton, D., Cuzick, J.: The EM algorithm for Cox's regression model using GLIM. J. R. Stat. Soc. Ser. C 34(2), 148-156 (1985)

Coff, R.: Human assets and management dilemmas: coping with hazards on the road to resource-based theory. Acad. Manag. Rev. 22(2), 374-402 (1997)

Darr, E., Argote, L., Epple, D.: The acquisition, transfer and depreciation of knowledge in service organizations: productivity in franchises. Manag. Sci. 41(11), 1750-1762 (1995)

Doeringer, Peter B., Piore, Michael J.: Internal labor markets and manpower analysis, Massachusetts. D.C. Heath and Company, Lexington (1971)

Dunne, T., Roberts, M., Samuelson, L.: Patterns of firm entry and exit in US manufacturing industries. Rand J. Econ. 19(4), 495-515 (1988)

Dunne, T., Roberts, M.J., Samuelson, L.: The growth and failure of U.S. manufacturing plants. Q. J. Econ. 104(4), 671-698 (1989)

Dutton, J., Starbuck, W.: Diffusion of an intellectual technology. In: Krippendorff, K. (ed.) Communication and control in society, pp. 289-511. Gordon \& Breach Science, New York (1978)

Elbers, C., Ridder, G.: True and spurious duration dependence: the identifiability of the proportional hazard model. Rev. Econ. Stud. 49, 403-409 (1982)

Frank, M.: An intertemporal model of industrial exit. Q. J. Econ. 103(2), 333-344 (1988)

Furtado, E., Karan, V.: Internal/external top management succession and firm performance. J. Financ. Strat. Decis. 7(1), 1-14 (1994)

Geroski, P., Mata, J., Portugal, P.: Founding conditions and the survival of new firms. Strat. Manag. J. 31(5), 510-529 (2010)

Ghoshal, S., Bartlett, C.: Creation, adoption and diffusion of innovations by subsidiaries of multinational corporations. J. Int. Bus. Stud. 19(3), 365-388 (1988)

Gibbons, R., Waldman, M.: Careers in organizations: theory and evidence. In: Ashenfelter, O., Card, D. (eds.) Handbook of labor economics, vol. 3, pp. 2373-2437. Elsevier, Amsterdam (1999)
Greenwald, B.: Adverse selection in the labor market. Garland, New York (1979)

Greve, H.: Patterns of competition: the diffusion of a market position in radio broadcasting. Adm. Sci. Q. 41(1), 29-60 (1996)

Hougaard, P.: Survival models for heterogeneous populations derived from stable distributions. Biometrika 73, 387-396 (1986)

Huberman, A.: Improving social practice through the utilization of universitybased knowledge. Higher Educ. 12(3), 257-272 (1983)

Huson, M., Malatesta, P., Parrino, R.: Managerial succession and firm performance. J. Financ. Econ. 74(2), 237-275 (2004)

Ingram, P.: Organizational form as a solution to the problem of credible commitment: the evolution of naming strategies among US hotel chains, 1896-1980. Strat. Manag. J 17, 85-98 (1996)

Ingram, P., Baum, J.: Chain affiliation and the failure of manhattan hotels: 1898-1980. Admin. Sci. Q. 42(1), 68-102 (1997)

Jovanovic, B.: Job matching and the theory of turnover. J. Polit. Econ. 87(5), 972-990 (1979)

Kalnins, Arturs, Lafontaine, Francine: Too far away? The effect of distance to headquarters on business establishment performance. Am. Econ. J. Microecon. 5, 157-179 (2013)

Lancaster, T.: The econometric analysis of transition data. Cambridge University Press, Cambridge (1990)

Lauterbach, B., Vu, J., Weisberg, J.: Internal vs external successions and their effect on firm performance. Hum. Relat. 52(12), 1485-1504 (1999)

Lazear, E.: Why is there mandatory retirement? J. Polit. Econ. 87(6), 1261-1284 (1979)

Lazear, E., Oyer, P.: Internal and external labor markets: a personnel economics approach. Labor Econ. 11(5), 527-554 (2004)

Liebenz, M.: Transfer of technology: US multinationals and eastern Europe. Praeger Publishers, New York (1982)

Lima, F., Martins, P.: External recruitments and firm performance. Appl. Econ. Lett. 13(14), 911-915 (2006)

Martilla, J.: Word-of-mouth communication in the industrial adoption process. J. Market. Res. 8(2), 173-178 (1971)

Mata, J., Portugal, P.: Life duration of new firms. J. Ind. Econ. 42(3), 227-245 (1994)

Mata, J., Portugal, P., Guimarães, P.: The survival of new plants: entry conditions and post-entry evolution. Int. J. Ind. Org. 13(4), 459-482 (1995)

Mills, D., Schumann, L.: Industry structure with fluctuating demand. Am. Econ. Rev. 75(4), 758-767 (1985)

Mitchell, W.: The dynamics of evolving markets: the effects of business sales and age on dissolutions and divestitures. Adm. Sci. Q. 39(4), 575-602 (1994)

Murphy, K.: Executive compensation. In: Ashenfelter, O., Card, D. (eds.) Handbook of labor economics, vol. 3, pp. 2485-2525. Elsevier, Holland (1999)

Nelson, R., Winter, S.: An evolutionary theory of economic change. Harvard University Press, Cambridge (1982)

Rothwell, R.: Some problems of technology transfer into industry: examples from the textile machinery sector. IEEE Trans. Eng. Manag. 25(1), 15-20 (1978)

Tavares, M., Carneiro, A., Varejão, J.: The spatial dimension of internal labor markets. J. Reg. Sci. 58(1), 181-203 (2018)

Teece, D.: Capturing value from knowledge assets. The new economy, markets for know-how and intangible assets. Calif. Manag. Rev. 40(3), 55-79 (1998)

Tushman, M.: Communication across organizational boundaries: special boundary roles in the innovation process. Adm. Scence Q. 22(4), 587-605 (1977) 
Wernerfelt, B.: A resource-based view of the firm. Strat. Manag. J. 5(2), 171-180 (1984)

Xue, X., Brookmeyer, R.: Bivariate frailty model for the analysis of multivariate survival time. Lifetime Data Anal. 2, 277-290 (1996)

Youndt, M., Snell, S., Dean, J., Lepak, D.: Human resource management, manufacturing strategy and firm performance. Acad. Manag. J. 39(4), 836-866 (1996)

\section{Publisher's Note}

Springer Nature remains neutral with regard to jurisdictional claims in published maps and institutional affiliations.
Submit your manuscript to a SpringerOpen ${ }^{0}$ journal and benefit from:

- Convenient online submission

- Rigorous peer review

- Open access: articles freely available online

- High visibility within the field

- Retaining the copyright to your article

Submit your next manuscript at $\boldsymbol{\nabla}$ springeropen.com 